\title{
Synthesis of a Polyconjugated Polymer by Aldol Condensation of 2,5-Diformylfuran and Acetone
}

\author{
Nikolay V. Tarabanko, Valery E. Tarabanko*, \\ Mikhail Yu. Chernyak, Konstantin L. Kaygorodov, \\ Alexander A. Kondrasenko, Nikolay G. Maksimov, \\ Maxim A. Lutoshkin and Nina I. Pavlenko \\ Institute of Chemistry and Chemical Technology SB RAS \\ Federal Research Center "Krasnoyarsk Science Center SB RAS" \\ 50/24 Akademgorodok, Krasnoyarsk, 660036, Russia
}

Received 14.04.2017, received in revised form 26.07.2017, accepted 04.12.2017

\begin{abstract}
Pioneer synthesis of the product of aldol polycondensation between 2,5-diformylfuran and acetone is presented. The synthesis was accomplished by a direct reaction of diformylfuran and acetone in dimethyl sulfoxide with addition of aqueous sodium hydroxide as a catalyst. The fact of the aldol condensation occurrence and formation of the polyconjugated oligomers in this system is confirmed by ${ }^{1} H$ nuclear magnetic resonance and molecular absorption spectroscopy. Cannizzaro reaction plays a significant side process role in the studied system, leading to the loss of diformylfuran's aldehyde groups and their inability to participate in polymer chain growth. A solid polymeric product of brown color was isolated with the yield of $28 \%$ based on the initial diformylfuran. The solid product is insoluble (judging by the lack of coloration in liquid) in various tested solvents: water, 1,4-dioxane, dimethyl sulfoxide, acetone, chloroform, or 1,2-dichloroethane with trifluoroacetic acid mixed in different proportions. The presence of polyconjugated chains in the solid product is confirmed by electron spin resonance spectroscopy.
\end{abstract}

Keywords: 2,5-diformylfuran, acetone, polymerization, polycondensation, polyconjugated polymers, aldol condensation, crotonic condensation.

DOI: 10.17516/1998-2836-0040.

(C) Siberian Federal University. All rights reserved

* Corresponding author E-mail address: veta@icct.ru, chem@icct.ru 


\title{
Синтез полисопряженного полимера
}

\section{альдольной конденсацией 2,5-диформилфурана}

\section{и ацетона}

\author{
Н.В. Тарабанько, В.Е. Тарабанько, \\ М.Ю. Черняк, К.Л. Кайгородов, А.А. Кондрасенко, \\ Н.Г. Максимов, М.А. Лутошкин, Н.И. Павленко \\ Институт химии и химической технологии СО РАН \\ ФИЦ «Красноярский научный изентр СО РАН» \\ Россия, 660036, Красноярск, Академгородок, 50/24
}

Впервые синтезирован продукт кротоновой (альдольной) поликонденсации
2,5-диформилфурана и ацетона. Синтез проведен непосредственным взаимодействием диформилфурана и ацетона в диметилсульфоксиде с добавками водного раствора $\mathrm{NaOH}$ в качестве катализатора. Факт протекания кротоновой конденсации и образования полисопряженногоолигомеравэтойсистемеподтвержденметодамипротонногомагнитного резонанса и электронной спектроскопии в УФ-и видимой области. Побочный процесс, реакиия Каннициаро, играет важную роль в процессе, приводя к потере альдегидных групп и обрыву цепей полимеризации. Выделен твердый полимерный продукт с выходом $28 \%$ в расчете на исходный диформилфуран. Продукт нерастворим в воде, диоксане, диметилсульфоксиде, ацетоне, хлороформе, дихлорэтане и его смесях с трифторуксусной кислотой в различных пропорциях. Наличие полисопряженных иеепей в полимере подтверждено спектроскопией ЭПР.

Ключевые слова: 2,5-диформилфуран, аџетон, полимеризация, поликонденсаџия, сопряженные полимеры, альдольная конденсачия, кротоновая конденсация.

\section{Introduction}

In the interest of preserving the stable global ecosystem under the constantly growing stress of the humanity's demands - in particular, this implies atmospheric carbon sequestration - it is necessary to supplant the consumption of fossil carbon forms in favor of renewable plant matter [1]. Vast amounts of plant-based carbohydrate biomass are available practically for free in the form of agricultural byproducts [2]. One of the products from acid-catalyzed conversion of carbohydrates is 5-hydroxymethylfurfural which may be then oxidized into 2,5-diformylfuran (hereinafter, DFF) (Fig. 1) [3]. Two aldehyde functional groups and an aromatic ring enable a wide variety of possible chemical reactions, which makes DFF an interesting "platform" compound for organic syntheses: e.g., cyclic and polymeric Schiff bases, antifungal agents and other pharmaceuticals, conductive and semiconductive polymers [4-6]. The latter utilization implies formation of $\pi$-polyconjugated unsaturated bonds. In case of DFF, such system of bonds may be created, e.g., in a single stage by aldol condensation with $\alpha-\beta, \alpha^{\prime}-\beta^{\prime}$-saturated ketones - in the simplest case, with acetone (Fig. 2). Although syntheses 


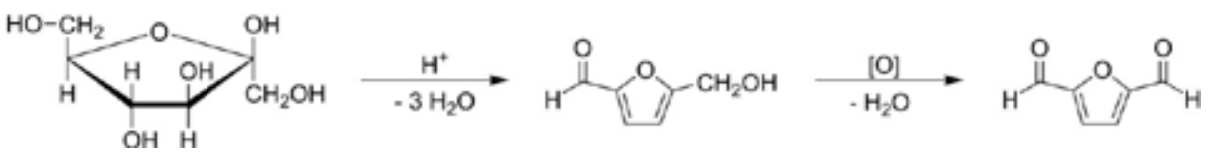

Fig. 1. The schematic of carbohydrate conversion into 5-hydroxymethylfurfural and subsequently into 2,5-diformylfuran

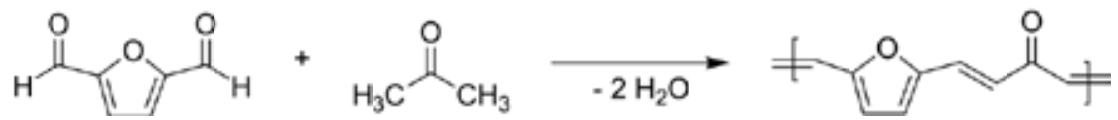

Fig. 2. The schematic of aldol polycondensation of 2,5-diformylfuran and acetone

of polyconjugated Schiff bases from DFF are known [4-5], the process of DFF interaction with carbonyl compounds remains unexplored.

The goal of this paper is establishing the possibility of aldol polycondensation of 2,5-diformylfuran and $\alpha-\beta, \alpha^{\prime}-\beta^{\prime}$-saturated ketones exemplified by acetone. Although aldol condensation can take place with acid or base as a catalyst [7], we will use a basic catalyst (sodium hydroxide) in the interest of excluding side reactions of electrophilic substitution in the furan ring. The nature of the reactions taking place in this system and of the resulting oligomeric products will be studied by nuclear magnetic resonance and molecular absorption spectroscopy. Electron spin resonance spectroscopy will be used to elucidate the presence of polyconjugated bonds in the polymer.

\section{Experimental}

The following reactants and materials were used in this work: distilled water, dimethyl sulfoxide (hereinafter DMSO, pharmaceutical grade, $99 \%$ ), fructose (food grade), deuterated solvents for ${ }^{1} \mathrm{H}$ nuclear magnetic resonance (hereinafter NMR) spectroscopy (DMSO 99.9\%, chloroform $99.8 \%$, Cambridge Isotope Laboratories Inc.). Other mentioned reagents were graded no lower than GOST "pure for analysis".

Instrumental analysis methods. ${ }^{1} \mathrm{H}$ NMR spectra were recorded using a Bruker Avance III $600 \mathrm{MHz}$ spectrometer (Krasnoyarsk Regional Research Equipment Center of SB RAS). Theoretical simulation of NMR spectra based on compound structure was accomplished using the open web-service SPINUSWEB [8-12]. Electron spin resonance (hereinafter ESR) spectra were recorded using a Bruker Elexsys E580 spectrometer (Krasnoyarsk Regional Research Equipment Center of SB RAS). UV-Vis spectra were measured with the SS2109-UV scanning spectrophotometer (Leki Instruments, Finland) using 1 $\mathrm{cm}$ quartz cells, all measurements were performed at room temperature. The IR spectra were recorded in the range of $4000-400 \mathrm{~cm}^{-1}$ on the FTIR spectrometer Tensor-27 (Bruker, Germany). The sample for IR spectroscopy was prepared in a potassium bromide matrix.

Synthesis of 2,5-diformylfuran. DFF was obtained by oxidation of 5-hydroxymethylfurfural (hereinafter HMF) by barium manganate(VI) - a stoichiometric oxidant known to easily transform unsaturated alcohols into the corresponding aldehydes [13], and able to oxidize HMF into DFF with $93 \%$ yield [14]. 
HMF for the subsequent oxidation was obtained according to the previously reported technique [15].

Barium manganate was obtained as follows. $15.8 \mathrm{~g}$ of potassium permanganate was dissolved in $300 \mathrm{ml}$ of water, then three other solutions were simultaneously mixed in under intense stirring: $\mathrm{BaCl}_{2} \cdot 2 \mathrm{H}_{2} \mathrm{O}$ (24.9 g in $100 \mathrm{ml}$ of water), $\mathrm{KOH}$ ( $56 \mathrm{~g}$ in 100 of water), and $\mathrm{KI}$ ( $2 \mathrm{~g}$ in 20 of water). This mixture had been heated until boiling began, cooled down, filtered, and the solid was rinsed with water while still on the filter until obtaining apparently colorless washwater. The solid was then dried at 105 ${ }^{\circ} \mathrm{C}$ for 5 hours.

For the oxidation, $2.5 \mathrm{~g}$ of HMF was dissolved in $500 \mathrm{ml}$ of chloroform, and $50 \mathrm{~g}$ of $\mathrm{BaMnO}_{4}$ was added. The oxidation was conducted at room temperature under stirring for one day. The average yield of the raw unrefined product after the solvent evaporation is $1 \mathrm{~g}$. The raw product was then dissolved in propanol, the solution was filtered, then DFF was crystallized by cooling. Thereby refined product yield was $0.5 \mathrm{~g}$. Its NMR spectrum is presented in Fig. 3. The peak at $9.87 \mathrm{ppm}$ corresponds to the hydrogen atoms of the aldehyde groups, $7.36 \mathrm{ppm}$ is for the furan ring hydrogen atoms. The content of impurities is not high.

Synthesis of solid polycondensation product of 2,5-diformylfuran and acetone. The process was carried out in a glass tube with a PTFE-sealed stopper at room temperature. $100 \mathrm{mg}(0.8 \mathrm{mmol})$ of DFF was dissolved in $1 \mathrm{ml}$ of DMSO, then $24 \mathrm{mg}(0.4 \mathrm{mmol})$ of acetone was added. Into this solution, $0.1 \mathrm{ml}$ of a catalyst solution (obtained by dissolving $250 \mathrm{mg} \mathrm{NaOH}$ in $2 \mathrm{ml}$ of water) was added, which corresponds to the alkali concentration in the reaction mass of approximately $0.3 \mathrm{mmol} / \mathrm{ml}$. The reaction solution immediately assumes black (deep yellow upon dilution) coloration. Then, another

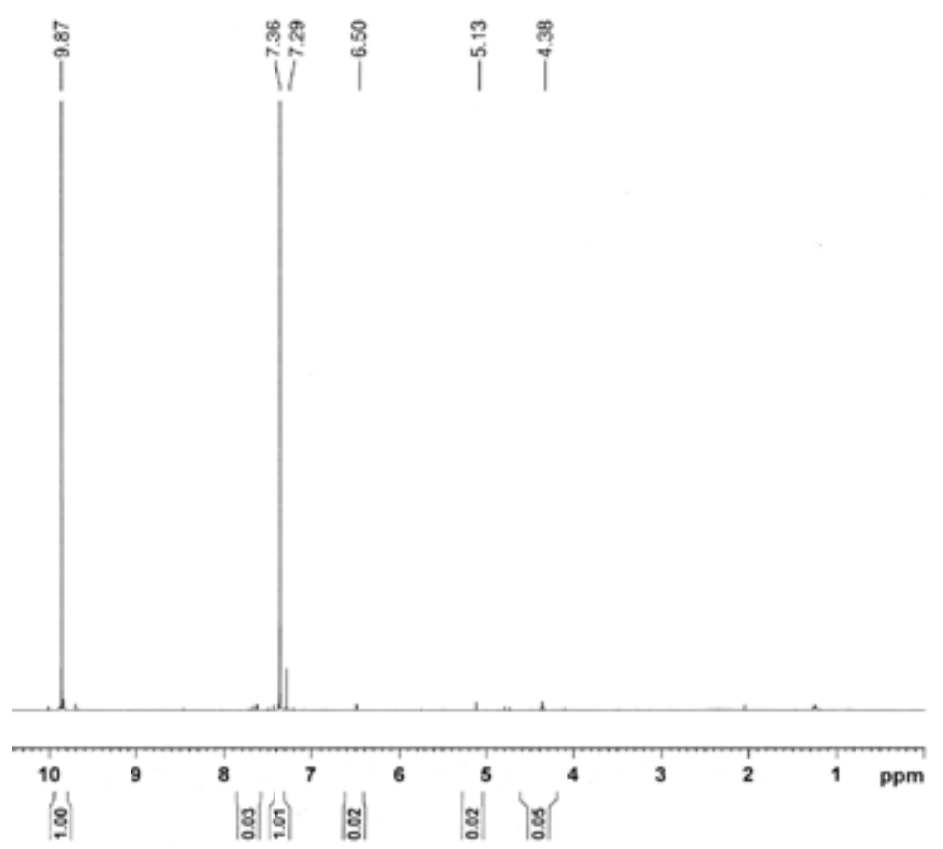

Fig. 3. ${ }^{1} \mathrm{H}$ nuclear magnetic resonance spectrum of the synthesized 2,5-diformylfuran as used in this study. The solvent is $\mathrm{CDCl}_{3}$. The indicators above show chemical shift values, the indicators below are for peaks' relative integral intensity values 
acetone batch $(24 \mathrm{mg}$ ) followed by $0.1 \mathrm{ml}$ of the catalyst solution were added. Over several following days the reaction solution thickens, and eventually flakes of the solid product congeal. After 30 days of the reaction, the product was rinsed with water until obtaining neutral $\mathrm{pH}$ of the washwater. Then, the product was left to soak in pure water for one day which was afterwards decanted; this soaking procedure was done five times total. The product was then dried at room temperature for two weeks, and afterwards at $105{ }^{\circ} \mathrm{C}$ for one hour. The eventual yield of the solid was $33 \mathrm{mg}$ which corresponds to $28 \%$ of the theoretical yield assuming quantitative conduction of the reaction shown in Fig. 2. The final product is black granular substance with lustrous surface that is easily ground into fine brown powder in an agate mortar.

Dissolution of the solid polymer. $2 \mathrm{mg}$ of the product obtained as described above and ground in an agate mortar was mixed with $1 \mathrm{ml}$ of a solvent at room temperature (we tested water, 1,4-dioxane, dimethyl sulfoxide, acetone, chloroform, and also 1,2-dichloroethane with trifluoroacetic acid mixed in varying proportions $-0: 1,1: 2,1: 1,2: 1,1: 0)$. The test tube was occasionally agitated over 30 minutes. Then the liquid was filtered, and visual comparison with the initial solvent was made to determine color change.

\section{Characterization of oligomerization in aldol condensation of 2,5-diformylfuran and acetone}

$\pi$-conjugation of multiple unsaturated bonds leads to bathochromic effect (shift of UV-Vis light absorption bands towards longer wavelength) compared to structures with fewer conjugated bonds [16]. Formation of the polymer according to Fig. 2 implies inclusion of the double bonds of the reactants into a singular polyconjugated chain the length of which corresponds to the length of the polymeric molecule. Therefore, conduction of the polycondensation reaction should lead to a decrease of absorption intensity in peaks corresponding to the reactants as the latter are depleted, and simultaneously new absorption bands should manifest at progressively longer wavelengths as the length of the polycondensation product molecules increases (at least, until the increase of the bathochromic shift becomes limited by molecular deformation due to thermal agitation, leading to the loss of double bonds coplanarity [17] which results in diminished bathochromic effect [16]).

The described changes of absorption spectra indeed take place in practice. Fig. 4 presents the light absorption spectra of the initial reactants, and of the reaction products after the catalyst addition. Recording of spectra at wavelengths shorter than $260 \mathrm{~nm}$ is restricted by strong absorption due to the solvent. With the presented axis scale, the acetone peak (264 nm, $\lg \varepsilon=4.25$ [18]) would reach the ordinate value $\approx 5-10$ in the initial reactants spectrum, and it appears to be mostly indistinguishable, obstructed by the diformylfuran signal. Addition of sodium hydroxide $(3.75 \mu \mathrm{mol} \mathrm{NaOH}$ per one $\mathrm{ml}$ of the DMSO used for preparing the reactant solution) causes the diminishing of the reactants absorption band at $<320 \mathrm{~nm}$, and also the formation of the new absorption region - with the broad shoulder above $420 \mathrm{~nm}$, and with somewhat better defined band at 320-420 nm. An attempt may be made to compare this latter band to the spectrum of another compound described in literature - (4-hydroxybenzylidene)(4-carboxybenzylidene)acetone [19]. This compound (Fig. 5, I) is structurally similar to the product of condensation between one molecule of acetone with two molecules of DFF with subsequent replacement of one aldehyde group by a carboxylic one (Fig. 5, II). The absorption spectrum of the substance I features two overlapping peaks at 310 and $360 \mathrm{~nm}$, and when electrolytic dissociation of the carboxyl 


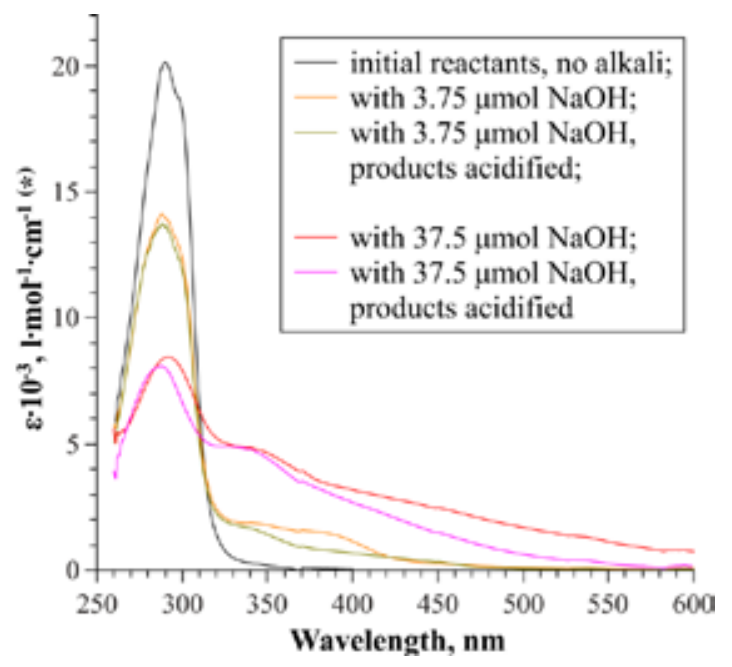

Fig. 4. UV-Vis absorption spectra of the reaction solutions in aldol condensation of 2,5-diformylfuran and acetone with different amounts of the catalyst (aqueous $\mathrm{NaOH}$ ). The reaction solution composition based on $1 \mathrm{ml}$ of the solvent (dimethyl sulfoxide): $4 \mathrm{mg}(32 \mu \mathrm{mol}) \mathrm{DFF}, \approx 1.2 \mu \mathrm{l}(16 \mu \mathrm{mol})$ acetone, $0.1 \mathrm{ml} \mathrm{NaOH}$ solution (the alkali amount per $1 \mathrm{ml}$ of DMSO is stated in the graph legend). Afterwards, to the samples marked as acidified, one drop of $10 \% \mathrm{HCl}$ was added. Single beam acquisition was performed, pure DMSO was used as the reference. (*) - molar absorbtivity values were calculated from absorbance based on the initial DFF amount

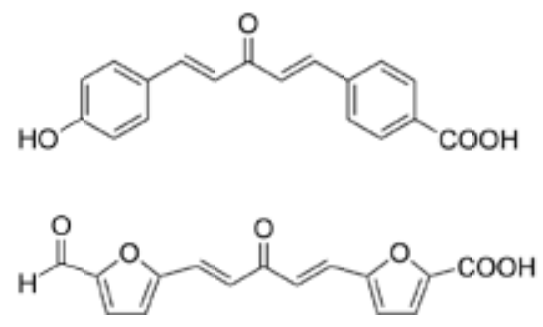

Fig. 5. Structure of (4-hydroxybenzylidene)-(4-carboxybenzylidene)acetone (I) and (5-hydroxyfurfurylidene)(5-carboxyfurfurylidene)acetone (II)

group takes place, the former peak is somewhat diminished but the latter exhibits more pronounced intensifying [19]. Acidifying the reaction mass that we obtained leads to the reverse phenomenon in the $320-420 \mathrm{~nm}$ band - in case of the compound I this could be interpreted as protonation of the dissociated carboxylic group. Considering the structural similarity between the substances I and II accentuated by the similar behavior when acidified, we assume that the spectrum of our reaction solution in the 320$420 \mathrm{~nm}$ range belongs to the compound II or something very similar (e.g., the aldehyde group might be replaced by another carboxylic group or a hydroxymethyl one).

Although the aldol condensation of diformylfuran as such does not cause transformation of aldehyde groups into carboxylic ones, it is possible to explain formation of the latter in the product molecules after the alkali addition by the occurrence of the Cannizzaro side reaction (Fig. 6). This reaction allows explaining why despite practically instantaneous darkening of the reaction solution, the condensation reaction soon halts and there remain stable significant amounts of the initial reactants: 
The reason for this is the consumption of alkali in the Cannizzaro reaction (Fig. 6), so there is no catalyst left to drive the aldol condensation (Fig. 2).

Addition of $37.5 \mu \mathrm{mol} \mathrm{NaOH}$ (per one $\mathrm{ml}$ of the DMSO used for preparing the reactant solution) causes qualitatively similar changes in the absorption spectrum as with ten-fold lower alkali amount, but this time these changes are more pronounced. The broad shoulder at $>370 \mathrm{~nm}$ probably corresponds to the oligomeric products of the aldol condensation with different chain lengths. Considerable diminishing of this absorption band after acidifying can be explained by the presence of terminal carboxylic groups that formed as the result of the Cannizzaro side reaction (Fig. 6). Acidifying causes protonation of these dissociated groups which leads to the spectral effects described above for the compounds I and II (Fig. 5)

An attempt to elucidate the reactions taking place in the reaction mass with the help of nuclear magnetic resonance spectroscopy was undertaken. Fig. 7 presents the ${ }^{1} \mathrm{H}$ NMR spectrum of the initial reactants. Besides the already familiar peaks of 2,5-diformylfuran (Fig. 3), there are signals corresponding to water (3.5 ppm), dimethyl sulfoxide (2.6 ppm), and acetone (2.08 ppm).

Addition of the catalyst (aqueous $\mathrm{NaOH}$ ) causes the signal of acetone (which was taken in two-fold shortage compared to DFF) to disappear, while the aldehyde group signal of DFF is broadened. The latter result can be explained by the formation of numerous compounds: the products of the aldehyde groups substitution by carboxylic or hydroxymethyl ones (due to the Cannizzaro reaction), and the products of the intended reaction with different chain lengths. Besides, there are new broad signals in the 6-8 ppm region. These signals are in satisfactory agreement with the theoretically simulated<smiles>[R]c1ccc(C=Cc2ccc(CO)o2)o1</smiles>

Fig. 6. Cannizzaro reaction with formylfuran (furfural) and its derivatives

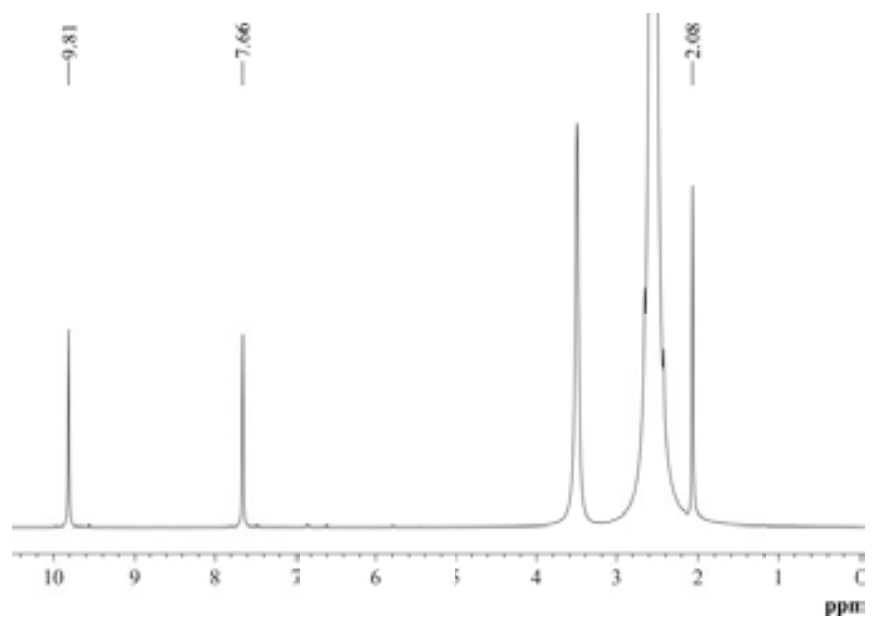

Fig. 7. ${ }^{1} \mathrm{H}$ NMR spectrum of the initial reactants for the aldol condensation of 2,5-diformylfuran and acetone. Composition of the solution: $0.5 \mathrm{ml}$ DMSO, $0.5 \mathrm{ml}$ DMSO-D $_{6}, 40 \mathrm{mg}$ DFF $(0.32 \mathrm{~mol} / \mathrm{l}), \approx 12 \mu 1$ acetone $(0.16$ $\mathrm{mol} / \mathrm{l})$ 
spectrum of the oligomer presented in Fig. 8. Any attempts to quantitatively estimate the amount of the condensation products based on, e.g., the new signals in the region of the acetylidenic protons (6-6.8 $\mathrm{ppm}$ ) do not seem productive due to inevitable errors caused by hydrogen exchange between acetone, DMSO, and the reaction medium [20, 21].

For reliable evidence of the Cannizzaro reaction taking place in the studied system, we present the fact that despite the presence of aldehyde groups in the reaction mass described by Fig. 8 (9-10 ppm), addition of a new acetone batch to it does not cause continued condensation reaction - as evidenced by the spectrum in Fig. 9. Obviously, this mixture no longer contains the condensation catalyst $(\mathrm{NaOH})$ because it was consumed in the Cannizzaro side reaction. To continue the intended reaction from this point, another batch of the catalyst has to be added. This would lead to the formation of the solid product as described in the Experimental section.

\section{Characterization of the solid product of polycondensation between 2,5-diformylfuran and acetone}

Attempts at dissolving the polymer obtained as described in the Experimental section were undertaken. The following solvents were tested: water, 1,4-dioxane, dimethyl sulfoxide, acetone, chloroform, and also 1,2-dichloroethane with trifluoroacetic acid mixed in varying proportions $0: 1,1: 2,1: 1,2: 1,1: 0$. None of these cases resulted in a change of liquid phase coloration. In the case of DMSO, the liquid phase was tested by ${ }^{1} \mathrm{H}$ NMR and did not reveal any signals in the range typical for furan rings or conjugated vinyl protons (6-8 ppm). Taking into account the considerable light absorption ability of the condensation products (Fig. 4), we conclude - based on the lack of liquid phase coloration - that the polymer is insoluble under the tested conditions. However, it should be noted that the insolubility problem is common for polyconjugated polymers without special

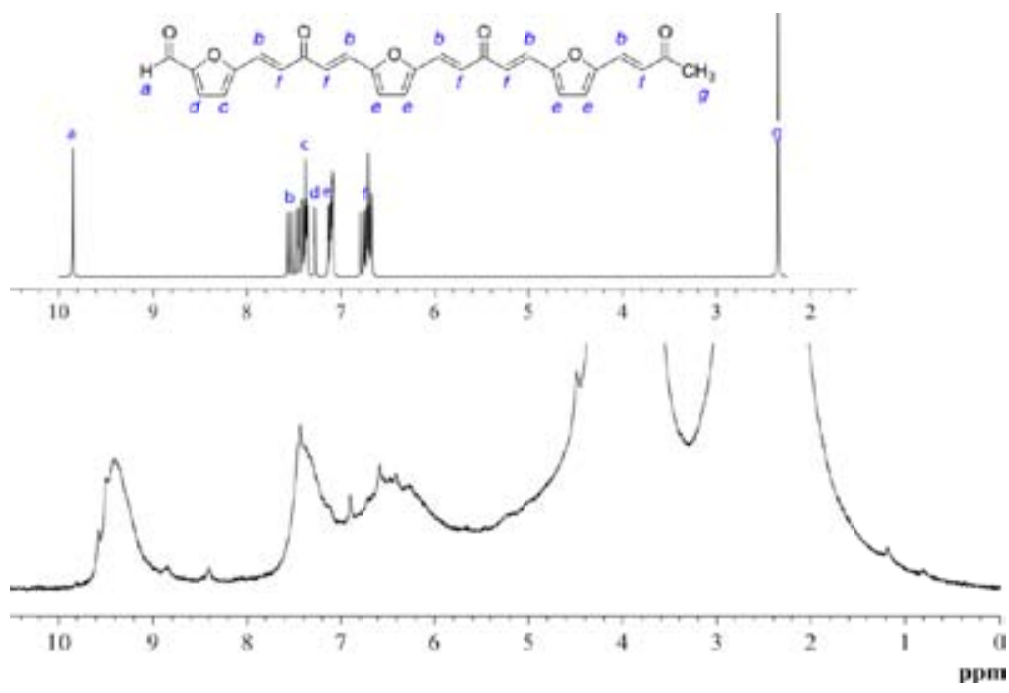

Fig. 8. Below: ${ }^{1} \mathrm{H}$ NMR spectrum of the reaction solution after the catalyst addition. The initial mixture composition is described in the caption of Fig. 7; $0.1 \mathrm{ml}$ of aqueous $\mathrm{NaOH}$ (made from $100 \mathrm{mg} \mathrm{NaOH}$ and $2 \mathrm{ml}$ water) was added, resulting alkali concentration in the reaction mass $\approx 4.5 \mathrm{~g} / 1(0.11 \mathrm{~mol} / \mathrm{l})$. Above: theoretically simulated spectrum of the presented compound. Indices near the peaks correspond to the atoms labeled in the structural formula 


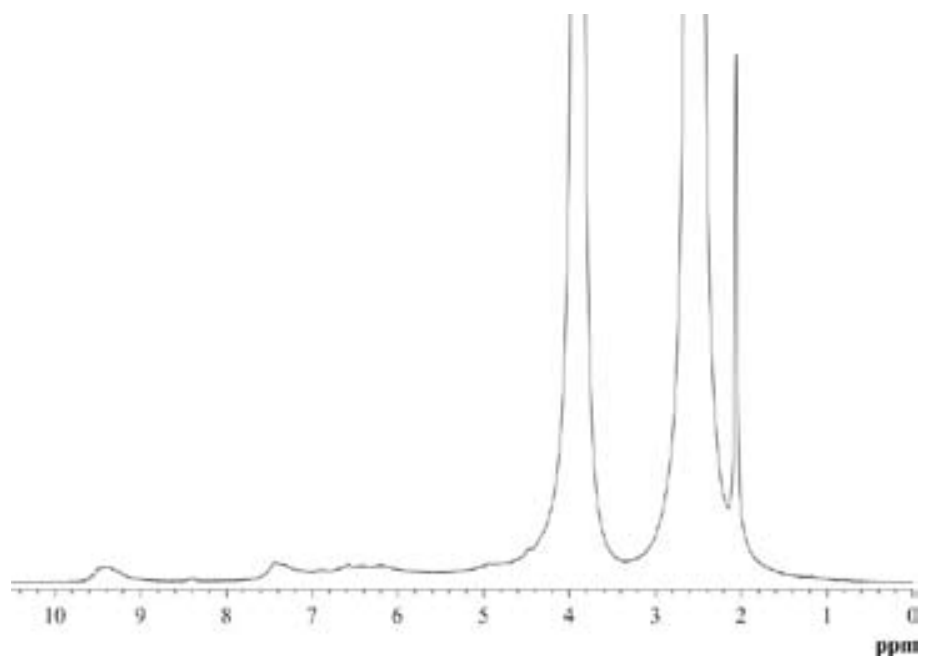

Fig. 9. ${ }^{1} \mathrm{H}$ NMR spectrum of the reaction mass after the addition of a new acetone batch, $\approx 12 \mu \mathrm{l}(0.16 \mathrm{mmol})$. The acetone peak is evident at $2.1 \mathrm{ppm}$. The reaction mass prior to this addition was obtained as described in the Caption of Fig. 8

functionalization [22]. This problem may also be aggravated by cross-linkage of the polymer chains. This phenomenon is typical to varying extents in all unsaturated polymers, and in polyconjugated chains constructed from acyclic monomers (like polyacetylene) it can occur spontaneously under relatively mild conditions [23]. In the substance we synthesized, such cross-linkage may affect the acetylidenic fragments of the polymeric molecules.

Further analysis of the obtained polymer's structure and properties is restricted by its insolubility. An attempt was made to characterize the solid sample (ground in an agate mortar) with electron spin resonance spectroscopy. The spectrum presented in Fig. 10 exhibits a somewhat anisotropic signal $\left(g_{0}=2.0044, \Delta H=7 G\right)$ that can be attributed to paramagnetic species of radical nature. Notable deviation of the $\mathrm{g}$-factor from the free electron value (2.0023) shows partial delocalization of the spin density towards the oxygen atoms contained in the polymeric molecules. The signal shape is satisfactorily approximated with a Gauss contour, which suggests considerable influence of unresolved hyperfine structure (hereinafter HFS) on the broadening of this signal. Taking the composition of this polymer into account, considerable effect of the hydrogen nuclei on the HFS can be expected. Considering the polyconjugation of double bonds in this polymer, delocalization of an uncoupled electron in the conjugated system can take place. In a system of pseudo-equivalent protons that contribute equally to the unresolved HFS, the shape of the ESR signal will be dictated by binomial distribution of the intensities of individual signals. It is known that the line shape determined by binomial distribution of intensities from unresolved HFS generated by numerous nuclei is a Gauss contour. This agrees with the shape of the experimental signal presented in Fig. 10.

To estimate the number of the pseudo-equivalent hydrogen nuclei that contribute to the unresolved HFS of the measured signal, we will derive the relation between the number of such nuclei and the theoretical signal width (we assume the width to equal the distance between the peaks of the first derivative of the absorption signal, which corresponds to the ESR measurement technique). Defining the distance between the components of the binomial distribution as unit, the distance between the 


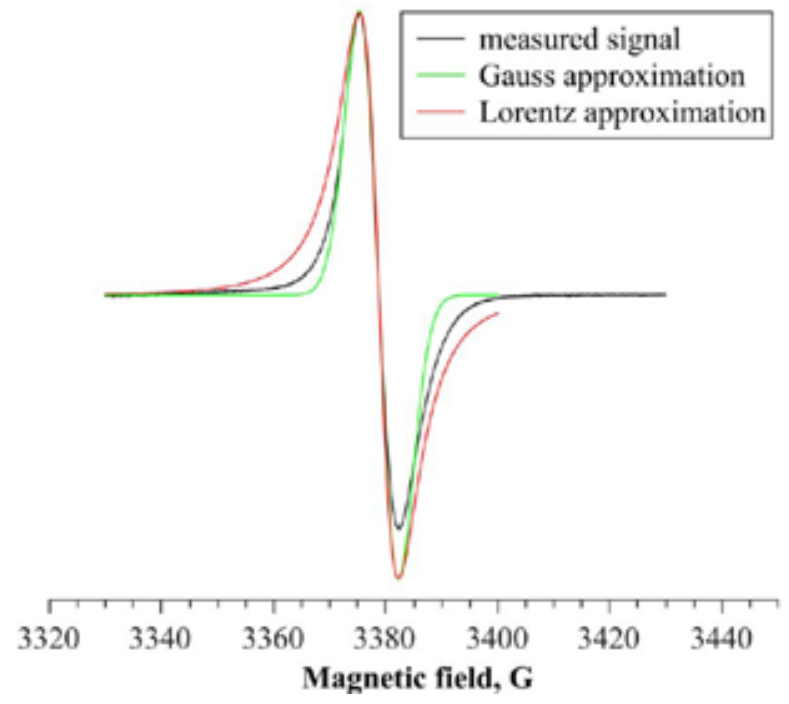

Fig. 10. Electron spin resonance spectrum of the synthesized polymeric sample and its approximation with Gauss and Lorentz contours

maxima of the first derivative will be $(\mathrm{N}+2)^{0.5}$, where $\mathrm{N}$ is the total number of particles with the nuclear spin $\mathrm{I}=1 / 2$. Considering how the distance between the two outermost components of the binomial distribution remains constant when spin density delocalization takes place $\left(\mathrm{A}_{\max }\right.$ that equals the sum of HFS constants from individual nuclei), the distance between neighboring components of the binomial distribution will be $A_{\max } / N$. The signal width as defined earlier then equals $\Delta H=A_{\max }(N+2)^{0.5} / N$, which allows expressing the number of the pseudo-equivalent hydrogen nuclei as $N \approx\left(A_{\max } / \Delta H\right)^{2} . A_{\max }$ can be estimated from literature data on various radical species [24]. In these radicals, uncoupled electrons are localized at individual carbon chain fragments (HFS constants for $\alpha$ - and $\beta$-protons are on average equal, amounting to $25 \mathrm{G}$; contributions to HFS from hydrogen atoms farther than that are quite small but sufficient to generate unresolved HFS components in ESR spectra). Based on the assumed polymer structure, one has to account for five $\alpha$ - and $\beta$-protons if the radical center is at the (former) carbonyl group after it attaches a hydrogen atom which, e.g., detached from another molecule, or for two $\alpha$ - and $\beta$-protons if the radical center is created by abstraction of any of the hydrogen atoms. This means that in one link of the polymer chain (as shown in Fig. 2) there are six carbon atoms that have two neighboring $\alpha$ - and $\beta$-protons, and one carbon atom that may have five such neighbors. This averages to $\approx 2.4$ hydrogen atoms per radical center. Thus, the $\mathrm{A}_{\max }$ value when the spin density is localized at one carbon atom in the polymer molecule will be $61 \mathrm{G}$. Then, the total number of the pseudo-equivalent hydrogen atoms calculated from the equation $\mathrm{N} \approx\left(\mathrm{A}_{\max } / \Delta \mathrm{H}\right)^{2}$ attains around 76 . Dividing this number by the number of hydrogen atoms per one link (specifically, six) we obtain the average length of the polymeric fragment where the delocalization of the uncoupled electron occurs: 12.7 furfurylidenacetylidenic links. The obtained results suggest significant influence of $\pi$-conjugation on the nature of spin density delocalization along the polymer chains.

Fig. 11 shows the infrared spectrum of the obtained polymer. Intense bands at 1603 and $1711 \mathrm{~cm}^{-1}$, and the region between them correspond to signals of conjugated chains $\mathrm{C}=\mathrm{C}-\mathrm{CO}-\mathrm{C}=\mathrm{C}$ and furan 


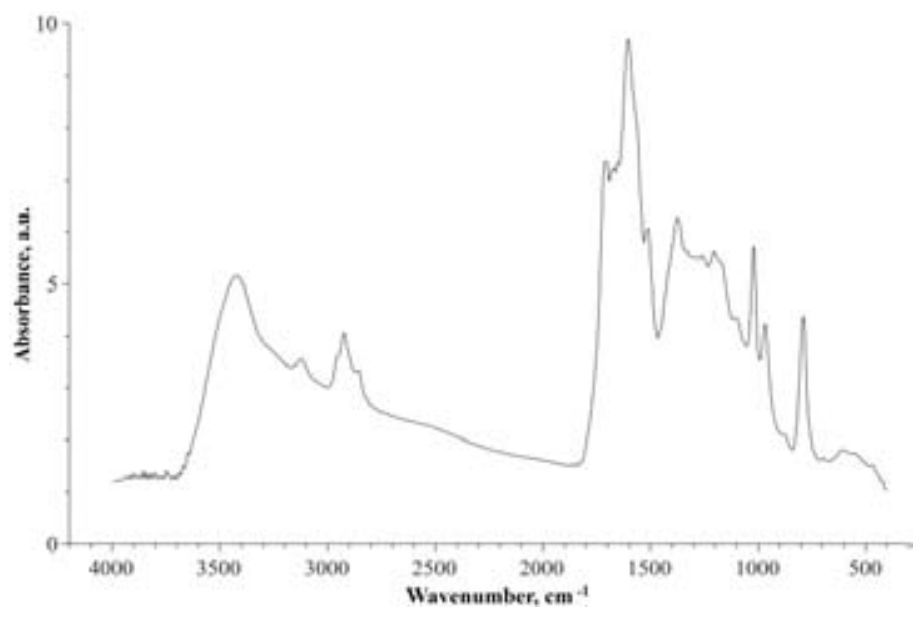

Fig. 11. Infrared spectrum of the synthesized polymeric sample

rings [25]. Signal at $3400 \mathrm{~cm}^{-1}$ corresponds to hydroxyl group oscillations and probably belong to the products of the Cannizzaro side reaction.

\section{Conclusion}

For the first time, the possibility of aldol polycondensation between 2,5-diformylfuran and acetone with formation of polyconjugated products has been presented. This demonstrates the practical possibility of polyconjugated systems synthesis based on renewable plant feedstocks and, potentially, of further inquiry into derivative semiconducting materials. Similar syntheses can probably be carried out by replacing acetone with a ketone that is also produced from plant matter, e.g., levulinic (4-oxapentanoic) acid [26] and its derivatives.

The obvious shortcoming of the alkaline catalyst used in this work is its propensity for the Cannizzaro side reaction involving the aldehyde groups of diformylfuran and the terminal aldehyde groups of growing polymer chains. This leads to nonproductive waste of diformylfuran, and to limitation of the maximum polymer chain length because destruction of the terminal - $\mathrm{CHO}$ groups leads to the inability to continue condensation according to the reaction shown in Fig. 2. Clearly, synthesis of diformylfuran-ketone polymers can only attract practical interest if a condensation catalyst more selective than alkali is found. Examples of aldol condensation over solid catalysts are known [27], but this variant also appears unpromising due to the hereinabove described solubility complications and subsequent catalyst surface obstruction. Immobilized catalytic systems may have more success in this situation. However, detailed inquiry into this subject falls outside of the scope of this work and should be the subject of further research.

\section{References}

1. Corma A., Iborra S., Velty A. Chemical routes for the transformation of biomass into chemicals. Chemical reviews 2007. Vol. 107, Iss. 6, P. 2411-2502. https://doi.org/10.1021/cr050989d.

2. Варфоломеев С.Д., Моисеев И.И., Мясоедов Б.Ф. Энергоносители из возобновляемого сырья. Химические аспекты. Вестник Российской академии наук 2009. Т. 79, № 7, С. 595.-604. 
[Varfolomeev S.D., Moiseev I.I., Myasoedov B.F. Energy carriers from renewable raw materials. Herald of the Russian Academy of Science 2009. V. 79. No. 7, p. 595-604. (In Russ.)].

3. Tong X.L., Ma Y., Li Y.D. Biomass into chemicals: Conversion of sugars to furan derivatives by catalytic processes. Applied Catalysis A-General 2010. Vol. 38, P. 1-13.

4. Amarasekara A. S. Renewable resources based polymers: Synthesis and characterization of 2,5-diformylfuran-urea resin. Eur. Polym. J. 2009. Vol. 45, P. 595.

5. Ma J. P. et. al. Synthesis and properties of furan-based imine-linked porous organic frameworks. Polym. Chem. 2009. Vol. 3, P. 2346.

6. Sanchez-Vazquez A., Hailes C., \& Evans G. Hydrophobic Polymers from Food Waste: Resources and Synthesis. Polymer Reviews 2013. Vol. 53(4), P. 627-694. https://doi.org/10.1080/15583724.2013.8 34933.

7. Марч Дж. Органическая химия. Реакции, механизмы и структура. М.: Мир, 1987, т. 3, с. 384. [March J.Advanced Organic Chemistry: Reactions, Mechanisms, and Structure. Moscow: Mir, 1987. Vol. 3, P 384. (In Russ.)].

8. Binev Y., Marques M.M., Aires-de-Sousa J. Prediction of 1H NMR coupling constants with associative neural networks trained for chemical shifts. J. Chem. Inf. Model. 2007. Vol. 47(6), P. 20892097.

9. Aires-de-Sousa J., Hemmer M., Gasteiger J. Prediction of 1H NMR Chemical Shifts Using Neural Networks. Analytical Chemistry 2002. Vol. 74(1), P. 80-90.

10. Binev Y., Corvo M., Aires-de-Sousa J. The Impact of Available Experimental Data on the Prediction of 1H NMR Chemical Shifts by Neural Networks. J. Chem. Inf. Comp. Sci. 2004. Vol. 44(3), P. 946-949.

11. Binev Y., Aires-de-Sousa J. Structure-Based Predictions of 1H NMR Chemical Shifts Using Feed-Forward Neural Networks. J. Chem. Inf. Comp. Sci. 2004. Vol. 44(3). P. 940-945.

12. Binev Y., Marques M.M., Aires-de-Sousa J. Prediction of $1 \mathrm{H}$ NMR coupling constants with associative neural networks trained for chemical shifts. J. Chem. Inf. Model. 2007. Vol. 47(6), P. 20892097.

13. Togo G., Fernandez M. Oxidation of Alcohols to Aldehydes and Ketones. A Guide to Current Common Practice. 2006. Springer Science+Business Media, Inc. 385 p.

14. El-Hajj T.; Masroua A., Martin J. C., Descotes G. Synthesis of 5-hydroxymethylfuran-2carboxaldehyde and its derivatives by acidic treatment of sugars on ion-exchange resin. Bull. Soc. Chim. Fr. 1987. P. 855-860.

15. Тарабанько В.Е., Черняк М.Ю., Смирнова М.А., Челбина Ю.В. Низкотемпературный синтез 5-гидроксиметилфурфурола. Химия растительного сырья. 2011. № 1. С. 87-92. [Tarabanko V. E., Chernyak M.Yu., Smirnova M.A., Chelbina Yu.V. Low-temperature synthesis of 5-hydroxymethylfurfural. The chemistry of plant raw material 2011, No. 1, p. 87-92. (In Russ.)].

16. L. D. S. Yadav. Organic Spectroscopy. 2005 Dordrecht (Germany). Springer. 324 p.

17. Sterpone F., Rossky P.J. Molecular Modeling and Simulation of Conjugated Polymer Oligomers: Ground and Excited State Chain Dynamics of PPV in the Gas Phase. The Journal of Physical Chemistry B 2008. Vol. 112 (16), P. 4983-4993 https://doi.org/10.1021/jp711848q.

18. Talrose V., Stern E.B., Goncharova A.A., Messineva N.A., Trusova N.V., Efimkina M.V. UV/ Visible Spectra" in NIST Chemistry WebBook, NIST Standard Reference Database Number 69, Eds.

$$
-463-
$$


P.J. Linstrom and W.G. Mallard, National Institute of Standards and Technology, Gaithersburg MD, 20899, https://doi.org/10.18434/T4D303, (retrieved November 3, 2017).

19. Ulrich Oertel, Marina M. Dudkina, Hartmut Komber, Bettina Pilch, Andrey V. Tenkovtsev, Frank Boehme. A spectroscopic study on the dissociation behavior of 4-hydroxybenzylideneacetone type NLO chromophores in the presence of sodium hydroxide. Optical Materials 2006. Vol. 29, Iss. 4, P. 377-385, https://doi.org/10.1016/j.optmat.2005.11.001.

20. Jones J.R. Rates of abstraction of hydrogen, deuterium and tritium from acetone in alkaline media. Trans. Faraday Soc. 1965. Vol. 61, P. 95-99.

21. Buncel E., Symons E.A., Zabel A.W. The deuteroxide-catalyzed hydrogen exchange of dimethyl sulphoxide. Preparation of diperdeuteromethyl sulphoxide $\left(\mathrm{CD}_{3}\right)_{2} \mathrm{SO}$. Chem. Commun. (London) 1965. Iss. 9, P. 173-174.

22. Margolis J. Conductive Polymers and Plastics. Springer US, 1989 https://doi.org/10.1007/9781-4613-0851-5.

23. Fredericks R.J., Lynch D.G., Dan W.E. Thermal properties of poly(acetylene): On the origin of cuprene in reppe's cyclooctatetraene synthesis. Journal of Polymer Science Part C: Polymer Letters 1964. Vol. 2, Iss. 8, P. 803-808. https://doi.org/pol.1964.110020811.

24. Atkins P., Symons M. ESR spectra and the structure of inorganic radicals (Russian translation). Moscow: Mir, 1970, 310 p.

25. Pretsch E., Buehlmann P., Affolter C. Structure determination of organic compounds - Tables of spectra data. Berlin: Springer, 2000. 421 pp.

26. Тарабанько В.Е., Черняк М.Ю., Кузнецов Б.Н., Захарова О.В. Исследование процессов кислотно-каталитической дегидратации углеводов в присутствии бутанола при умеренных температурах. Химия растительного сырья 2002. № 2. C. 5-15. [Tarabanko V. E., Chernyak M.Yu., Kuznetsov B.N., Zakharova O.V. Investigation of the acid-catalyzed conversion in the presence of butanol at moderate temperatures. The chemistry of plant raw material 2002, No. 2, p. 5-12. (In Russ.)].

27. Jackson S.D., Hargreaves J.S.J., Lennon D., Kelly G.J. Catalysis in Application., Cambridge: The Royal Society of Chemistry, 2003. P. 129-135. http://dx.doi.org/10.1039/9781847550347. 